\title{
Assessment of Water Quality of Brahmani River using Correlation and Regression analysis
}

\section{Saroj Kumar Nayak ${ }^{1}$}

${ }^{1}$ M.Tech, Department of Civil Engineering, VSSUT, Odisha, India

\begin{abstract}
This work evaluates the surface water quality in terms of physico-chemical parameters of the Brahmani River, Odisha using statistical analysis involving the calculation of correlation coefficient and regression equation. Besides this, the work also highlights and draws attention towards the "Water Quality Index" in a simplified format which may be used at large and could represent the reliable picture of water quality. Surface water quality data is taken from OSPCB of various location i.e. Panposh D/S, Rourkela D/S, Rengali, Talcher U/S,
\end{abstract} Kamalanga D/S, Bhuban, Pattamundai and was assessed for summer, monsoon, winter for the years 2011, 2012, 2013, 2014 and 2015. Average of values, minimum of values and maximum of values of water quality parameters were obtained seasonally over the above mentioned years. Besides this, the standard deviation for the water quality parameters was also obtained for water quality parameters namely $\mathrm{pH}$, Temperature, DO, TDS, Alkalinity, $\mathrm{EC}, \mathrm{Na}^{+}, \mathrm{Ca}^{2+}, \mathrm{Mg}^{2+}, \mathrm{K}^{+}, \mathrm{F}^{-}, \mathrm{Cl}^{-}, \mathrm{NO}_{3}{ }^{-}, \mathrm{SO}_{4}{ }^{2-}$ and $\mathrm{PO}_{4}{ }^{2-}$. Seasonal changes in various physical and chemical parameters were analysed.The values obtained were compared with the guideline values for drinking water by Bureau of Indian Standard (BIS). A systematic correlation and regression study is carried out for three seasons, showed linear relationship among different water quality parameters. This provides an easy and rapid method of monitoring water quality. Highly significant $(0.8<\mathrm{r}<1.0)$, moderately significant $(0.6<\mathrm{r}$ $<0.8)$ and significant $(0.5<\mathrm{r}<0.6)$ correlations between the parameters have been worked out. High correlation coefficient has been observed between TDS,EC- $\mathrm{Na}^{+}, \mathrm{Ca}^{2+}, \mathrm{Cl}^{-}, \mathrm{SO}_{4}{ }^{2-}$; $\mathrm{Na}^{+}-\mathrm{Cl}^{-}$. From the collected quantities, certain parameters were selected to derive WQI for the variations in water quality of each designated sampling site. WQI of Brahmani River ranged from 36.7 to 44.1 which falls in the range of good quality of water.Panposh D/S and Rourkela D/S showed poor water quality in summer and winter season. It is shown that WQI may be a useful tool for assessing water quality and predicting trend of variation in water quality at differentlocations in the Brahmani River. 
Keywords: Major ions, Physicochemical parameters, Pearson's correlation matrix, Regression, Water Quality Index(WQI), Brahmani, Summer(S), Monsoon(M), Winter(W) 


\section{Introduction}

Water is the most important natural resource not only of a state or a country, but of the entire humanity. The prosperity of a nation depends primarily upon the judicious exploitation of this resource. Thus, it can be stated that the primary wealth of a nation is water, which flows in rivers and streams. The available fresh water to man is hardly $0.3-0.5 \%$ of the total water available on the earth and therefore, its judicious use is imperative(Ganesh and Kale 1995).Water is an essential requirement of human and industrial developments and it is one the most delicate part of theenvironment (Das and Acharya 2003).Rapid increase of industrialization, urbanization, and population increase in the lastfew decades have caused a dramatic increase in the demand for river water, aswell as significant deteriorations in water quality throughout the world(Chun et al 2001).

The Brahmani is a major seasonal river in theOdisha state of Eastern India. The Brahmani isformed by the confluence of the Sankh and SouthKoel rivers, and flows through the districts ofSundergarh, Kendujhar, Dhenkanal, Cuttack andJajpur. The Brahmani is formed by the confluenceof the rivers South Koel and Sankh near the majorindustrial town of Rourkela at $2215^{\prime} \mathrm{N}$ and $8447^{\prime} \mathrm{E}$. The treatment facilities of the Brahmaniriver are extremely limited. The water quality of variouslocations suffers very high levels of contamination. Due to the huge discharge of industrial wastes intothe Brahmani River, the water is getting polluted dayby day. The river Brahmani is being polluted by the effluents from steel plants andchemical industries in the river bed. (NibeditaPattnayak 2015).

It is a cumbersome task to regularly monitor all the parameters even if adequate manpower and laboratory facilities are available. Therefore, in recent years an easier and simpler approach based on statistical correlation, has been developed using mathematical relationship for comparison of physico-chemical parameters.Extensive research has been carried out on statistical analysis to assess the surface water quality. (Sharma et.al 2014) have assess the changes in water quality index of Ganges River at different locations in Allahabad, India using Pearson's correlation coefficient ( $r$ ) value which determined using correlation matrix to identify the highly correlated and interrelated water quality parameters. The correlation study and correlation coefficient values can help in selecting a few parameters which could be frequently measured to determine the status of water quality regularly (Patel et al. 2015). This correlation coefficient measures the degree of association or correlation that existsbetween the two variables. The greater the valueof it, the better is the fit and more useful theregression 
equation as predictive device. Thevalues of variance ratio, $\mathrm{F}$ is high and standarderror of estimation, $\mathrm{S}$ is also low which are also necessary in requirements for significant correlation. (Rastogi et al 2011). MeghaAgrawalet.al(2013) postulatedregression equation can be widely used for establishing some good correlations between physicochemical water parameters and these equations can be used to predict the contamination in river kosi.Navneetkumar (2010) found an approach to river water quality management though correlation study between various water quality parameters of Gaganriver at Mordabad,India. Daraigan et al (2011) studied that The linear correlation is very useful to get fairly accurate idea of quality of the ground water by determining a few parameters experimentally. The statistical analysis is cost effective and time saving as per Agarwal et al (2011).

WQI is desired to provide assessment of water quality trends formanagement purposes even though it is not meant especially as anabsolute measure of the degree of pollution or the actual water quality. Horton (1965) proposed the first water quality index. Application of WQI has been used for estimating water quality in rivers e.g. Sabarmati River, Gujarat by Shah et al (2015), Dokan Lake Ecosystem byAlobaidyet al. (2010), Ganges River along different locations of Allahabad (Sharma et.al 2014). These studies consider the water quality might change because of various natural and anthropogenic activities at different locations. In this study, WQI has been determined from measured parameters of theBrahmani river water, sampled from various sampling stations.
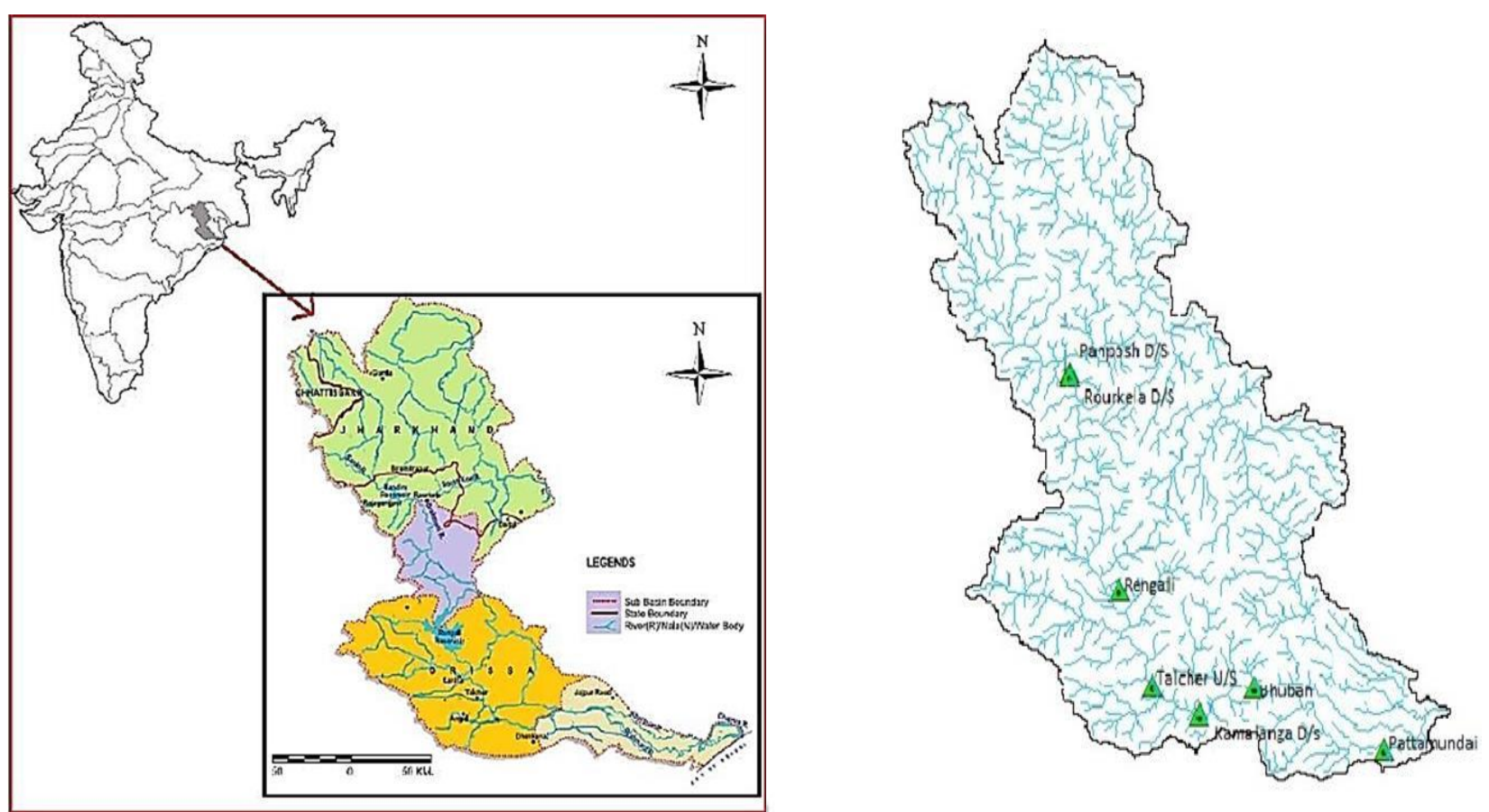

Fig. 1.Sketch of river Brahmani showing sampling locations. 


\section{Material and Method}

\subsection{Sample sites and Data collection}

For the Brahmani River seven sampling sites were selected as follows: Panposh D/S, Rourkela D/S, Rengali, Talcher U/S, Kamalanga D/S, Bhuban, Pattamundai as shown in Fig. 1. 15 physicochemical parameter namely $\mathrm{pH}$, Temperature, DO, TDS, EC, Alkalinity, $\mathrm{Na}^{+}$, $\mathrm{Ca}^{2+}, \mathrm{Mg}^{2+}, \mathrm{K}^{+}, \mathrm{F}^{-}, \mathrm{Cl}^{-}, \mathrm{NO}_{3}{ }^{-}, \mathrm{SO}_{4}{ }^{2-}$, and $\mathrm{PO}_{4}{ }^{2-}$ data of the year 2011, 2012, 2013, 2014 and 2015 were collected from OSPCB. These data were divided into three seasons namely summer (March-June), Monsoon(July-September) and Winter(October-February) for the statistical analysis.

\subsection{Statistical Analysis}

Statistical analysis was carried out using statistical package for social sciences (SPSSVersion 24). Statistical parameters viz., minimum, maximum, mean, SD, variance and correlation coefficient for physicochemical parameters are determined. The mean and standard deviations are calculated to know the parameters which are deviating from BIS standard. Correlation analysis measures the closeness of the relationship between chosen variables. If the correlation coefficient is nearer to +1 or -1 , it shows the perfect linear relationship between the two variables.In order to calculate correlation coefficients, correlation matrix was constructed by calculating the coefficients of different pairs of parameters and correlation for significance was further tested by applying $\mathrm{p}$ valve by Khatoon et al(2013). The variations are significant if $\mathrm{p}<0.05, \mathrm{p}<0.01$, and non-significant if $\mathrm{p}>0.05$. The significance is considered at the level of 0.01 and 0.05 (2- tailed analysis). This way analysis attempts to establish the nature of the relationship between the water quality parameters.

\subsection{Correlation coefficient and Linear Regression}

Correlation analysis measures the closeness of the relationship between chosen independent and dependent variables (Jain 2002, Sharma 2005, Singanan 1995). Correlation coefficient between two parameters $\mathrm{X}$ and $\mathrm{Y}$ calculated as

Correlation $(\mathrm{r})=\frac{\sum(\mathrm{X}-\overline{\mathrm{X}}) \cdot(\mathrm{Y}-\overline{\mathrm{Y}})}{\sqrt{\sum(\mathrm{X}-\overline{\mathrm{X}})^{2} \cdot \sum(\mathrm{Y}-\overline{\mathrm{Y}})^{2}}}$

Where $\bar{X}=\frac{\sum X}{n}$ and $\bar{Y}=\frac{\sum Y}{n}$ and 'n' is number of samples 
For good correlation value of $\mathrm{r}$ should be between $-1<\mathrm{r}<1$. The correlation between the parameters ischaracterized as strong, when it is in the range of +0.8 to1.0 and -0.8 to -1.0 , moderate when it is having value in therange of +0.5 to 0.8 and -0.5 to -0.8 , weak when it is in therange of +0.0 to 0.5 and- 0.0 to -0.5 by Nair et al (2005). In statistics, correlation is a broad class of statistical relationship between two or more variables. The correlation study is useful to find a predictable relationship which can beexploited in practice. It is used for the measurement of the strength and statistical significanceof the relation between two or more water quality parameters (Mehta, 2010).

The term regression stands for some sort of functionalrelationship between two or more related variables. It measures the nature and extent ofcorrelation and predicts the unknown values of one variable from known values of anothervariable.This analysisattempts to establish the nature of the relationship between the variables and thereby provides a mechanismfor prediction or forecasting by Kumar and Sinha (2010). Following regression equation is used to established correlation between parameters

$\widehat{\mathrm{Y}}=\mathrm{b}_{0}+\mathrm{b}_{1} \mathrm{x}$

Where, yand $\mathrm{x}$ are the dependent and independent variable respectively. ' $\mathrm{b}_{1}$ ' is the slope of line, ' $\mathrm{b}_{0}$ ' is intercepton y axis. The value of empirical parameters ' $\mathrm{b}_{1}$ ' and ' $\mathrm{b}_{0}$ ' arecalculated with the help of the following equation:

$$
\begin{gathered}
\mathrm{b}_{1}=\mathrm{r} \frac{\mathrm{S}_{\mathrm{y}}}{\mathrm{S}_{\mathrm{x}}} \\
\mathrm{b}_{0}=\mathrm{M}_{\mathrm{y}}-\mathrm{b}_{1} \mathrm{M}_{\mathrm{x}}
\end{gathered}
$$

Where, $\mathrm{M}_{\mathrm{X}}$ is the mean of $\mathrm{X}, \mathrm{M}_{\mathrm{Y}}$ is the mean of $\mathrm{Y}, \mathrm{S}_{\mathrm{X}}$ is the standard deviation of $\mathrm{X}, \mathrm{S}_{\mathrm{Y}}$ is the standard deviation of $\mathrm{Y}$, and $\mathrm{r}$ is the correlation between $\mathrm{X}$ and $\mathrm{Y}$.

\subsection{WQI Determination}

The method adopted for the calculation of WQI was as described by Hameed et al. (2010). To calculate WQI, a total of 12parameters were considered and each parameter was assigned with a definite weightage $\left(\mathrm{W}_{\mathrm{a}}\right)$ according to its relativeimportance on the overall quality of water which ranges from 1 to 5. Parameters which influence more significantlythe water quality were assigned weight 5 and 1 to that of the least influencing. Relative weights $\left(\mathrm{W}_{\mathrm{r}}\right)$ were calculated byusing the following formula: 
$\mathrm{W}_{\mathrm{r}}=\frac{W_{a i}}{\sum_{\mathrm{i}=1}^{\mathrm{n}} \mathrm{W}_{\mathrm{ai}}}$

Where $\mathrm{W}_{\mathrm{r}}=$ Relative weight, $\mathrm{W}_{\mathrm{a}}=$ assigned weight of each parameter, $\mathrm{n}=$ Number of parameters considered for the WQI. Thecalculated value of $\mathrm{W}_{\mathrm{r}}$ for the each parameter is given in the Table 1.

Then quality rating scale $(\mathrm{Q})$ has been measured for the each parameter by dividing its respective standardvalues as suggested in the BIS guidelines.

$\mathrm{Q}_{\mathrm{i}}=\left[\mathrm{C}_{\mathrm{i}} / \mathrm{S}_{\mathrm{i}}\right] \times 100$

To calculate the $\mathrm{Q}$ for the $\mathrm{DO}$ and $\mathrm{pH}$, the different methods were employed. The ideal values $\left(\mathrm{V}_{\mathrm{i}}\right)$ of $\mathrm{pH}$ (7.0) and DO (14.6)were deducted from the measured values in the samples (Hameed et al., 2010).

$\left.\mathrm{Q}_{\mathrm{pH}, \mathrm{DO}}=\left[\left(\mathrm{C}_{\mathrm{i}}-\mathrm{V}_{\mathrm{i}}\right)\right] /\left(\mathrm{S}_{\mathrm{i}}-\mathrm{V}_{\mathrm{i}}\right)\right] \times 100$

where $Q_{i}=$ quality rating scale, $C_{i}=$ measured concentration of each parameter, $S_{i}=$ drinking water standard values for theeach parameter according to BIS.

$\mathrm{SI}_{\mathrm{i}}=\mathrm{W}_{\mathrm{r}} \times \mathrm{Q}_{\mathrm{i}}$

$\mathrm{WQI}=\sum_{i=1}^{\mathrm{n}} \mathrm{SI}_{\mathrm{i}}$

The computed WQI values were classified according to proposed categorization of water quality (Yadav et al., 2010).

Table 1Relative weight of chemical parameters.

\begin{tabular}{|c|c|c|c|}
\hline Parameters & $\begin{array}{c}\text { BIS-Water Quality } \\
\text { Standard }\end{array}$ & $\begin{array}{c}\text { Weight } \\
\left(\mathbf{W}_{\mathbf{a}}\right)\end{array}$ & $\begin{array}{c}\text { Relative Weight } \\
\left(\mathbf{W}_{\mathbf{r}}\right)\end{array}$ \\
\hline $\mathrm{pH}$ & $6.5-8.5$ & 4 & 0.105263 \\
\hline $\begin{array}{c}\text { Dissolved Oxygen (mg/L) } \\
\text { Total Dissolved Solids } \\
(\mathrm{mg} / \mathrm{L})\end{array}$ & 5 & 4 & 0.131579 \\
\hline Alkalinity (mg/L) & 500 & 2 & 0.105263 \\
\hline
\end{tabular}




\begin{tabular}{|c|c|c|c|}
\hline $\begin{array}{c}\text { Electrical Conductivity } \\
(\mu \mathrm{S} / \mathrm{cm})\end{array}$ & $250-750($ Good Quality $)$ & 5 & 0.131579 \\
\hline $\mathrm{Na}^{+}(\mathrm{mg} / \mathrm{L})$ & 200 & 1 & 0.026316 \\
\hline $\mathrm{Ca}^{2+}(\mathrm{mg} / \mathrm{L})$ & 75 & 2 & 0.052632 \\
\hline $\mathrm{Mg}^{2+}(\mathrm{mg} / \mathrm{L})$ & 30 & 2 & 0.052632 \\
\hline $\mathrm{F}^{-}(\mathrm{mg} / \mathrm{L})$ & 1 & 3 & 0.052632 \\
\hline $\mathrm{Cl}^{-}(\mathrm{mg} / \mathrm{L})$ & 250 & 4 & 0.078947 \\
\hline $\mathrm{NO}_{3}{ }^{-}(\mathrm{mg} / \mathrm{L})$ & 45 & 4 & 0.105263 \\
\hline $\mathrm{SO}_{4}{ }^{2-}(\mathrm{mg} / \mathrm{L})$ & 200 & & \\
\hline
\end{tabular}

\section{Results and Discussion}

We have collected several water quality parameters, namely, temperature, $\mathrm{pH}$, electrical conductivity (EC), dissolvedoxygen (DO), total dissolved solids (TDS), major cations e.g. $\mathrm{Na}^{+}, \mathrm{K}^{+}, \mathrm{Mg}^{2+}, \mathrm{Ca}^{2+}$, major anions e.g. $\mathrm{F}^{-}, \mathrm{Cl}^{-}, \mathrm{SO}_{4}{ }^{2-}, \mathrm{NO}_{3}{ }^{-}, \mathrm{PO}_{4}{ }^{2-}$ and alkalinity at a total of seven sampling location of Brahmani river. The values obtainedin our studies were compared with the guideline values suggested by BIS (Indian Standard Specification for Drinking Water,2012). We have determined Pearson's correlation matrix followed by linear regression of highly significant parameters and then WQI is calculated.

\subsection{Trend analysis of physicochemical parameters}

\subsubsection{Summer season}

It is noticed that $\mathbf{p H}$ of water is found to be within desirable limit as per IS 10500:2012 i.e., 6.5-8.5. pH ranged from 5 to 8.5 which is best for plankton growthby Umavathi et.al, (2007). The measured values of DO in Brahmani River for summer season were found in the range 6.16 to $7.81 \mathrm{mg} / \mathrm{L} . \mathrm{DO}$ is highest at Rengali and lowest at Panposh D/S. The observed lower DO values in river water at Panposh D/S may be partly attributed to organic substances and bacterial load. The Dissolved oxygen in the water is lower than thepermissible limit of 8 $\mathrm{mg} / \mathrm{L}$ for good quality drinking water by $\mathrm{K}$. Jyotivenkatchalam et al 
(2010).Temperatureranges from 29.1 to $33.1^{\circ} \mathrm{C}$ over the different sampling stations of Brahmani River. The highest temperature is recorded at Kamalanga D/S and lowest at Panposh D/S. The fluctuation in temperature of river water usually depends on the season, geographic location, sampling time and temperatureof effluents entering the stream (Ahipathy\&Puttaiah, 2006). The TDS value was found to be from 86.38 to $191.69 \mathrm{mg} / \mathrm{L}$ which is within the desirable limit (BIS, $500 \mathrm{mg} / \mathrm{L}$ ). The values of TDS of most locations were found within permissible limit of $500 \mathrm{mg} / \mathrm{l}$ for drinking purpose (Huq\&Alam, 2005).Electrical conductivity usually used for indicating the total concentration of ionized constituents of water (Huq\&Alam, 2005). The EC value measured ranged from $145.37 \pm$ 21.50 to $334.95 \pm 75.15 \mu \mathrm{S} / \mathrm{cm}$ at the designated stations. The values of EC reflected good quality of water at these locations, as per standards by BIS $(250-750 \mu \mathrm{S} / \mathrm{cm}$-Good water).Increasing levels of conductivity and cations are the products of decomposition and mineralization of organic materials by Venkatesharaju et al. (2010). Alkalinitiesof Brahmani River at designated sampling stations were found in the range $54.63-78.50 \mathrm{mg} / \mathrm{L}$. The alkalinity of water is due to the salt of carbonates, bicarbonates, borates, silicates and phosphates along with hydroxyl ions in the free state by Agarwal et al. (2010). These values are within desirable limits suggested by BIS (200 mg/L).Major cations concentration at each sampling station showed the decreasing trend which followed the order as $\mathbf{C a}^{2+}>\mathbf{M g}^{2+}>$ $\mathbf{N a}^{+}>\mathbf{K}^{+}$. Concentration of $\mathbf{M g}^{2+}$ was found within desirable limit (BIS, $30 \mathrm{mg} / \mathrm{L}$ ) except at Panposh D/S which accounted $36.13 \mathrm{mg} / \mathrm{L}$. This may be due to the weaker biological activity of magnesium, as compared with the calcium, and also the higher solubility of magnesium sulphate and hydrocarbonate as compared the equivalent compounds of calcium, favour increase in $\mathrm{Mg}^{2+}$ concentration in water (Nikanorov et al. 2009). In the water of Brahmani River among anions, $\mathbf{F}^{-}$ions were found in range $0.32 \mathrm{mg} / \mathrm{L}$ to $1.70 \mathrm{mg} / \mathrm{L}$ where sites Panposh D/S and Rourkela D/S values are more than the desirable limit (BIS, $1 \mathrm{mg} / \mathrm{L}$ ). This is due to untreated or partly treated wastes and waste water discharge from industries to river (Moharana et al. 2013). The $\mathbf{S O}_{4}{ }^{2-}$ concentration is more in Panposh D/S and Rourkela D/S with respect to other anions.Panposh D/S, Rourkela D/S, Rengali and Talcher U/S shows significant increase in $\mathbf{P O}_{4}{ }^{2-}$ concentration may be due to industrial discharge and agricultural runoff having fertilizers. All other major anions are within the desirable limit. The trends of all the parameter along the sampling stations is shown in Fig. 2. 


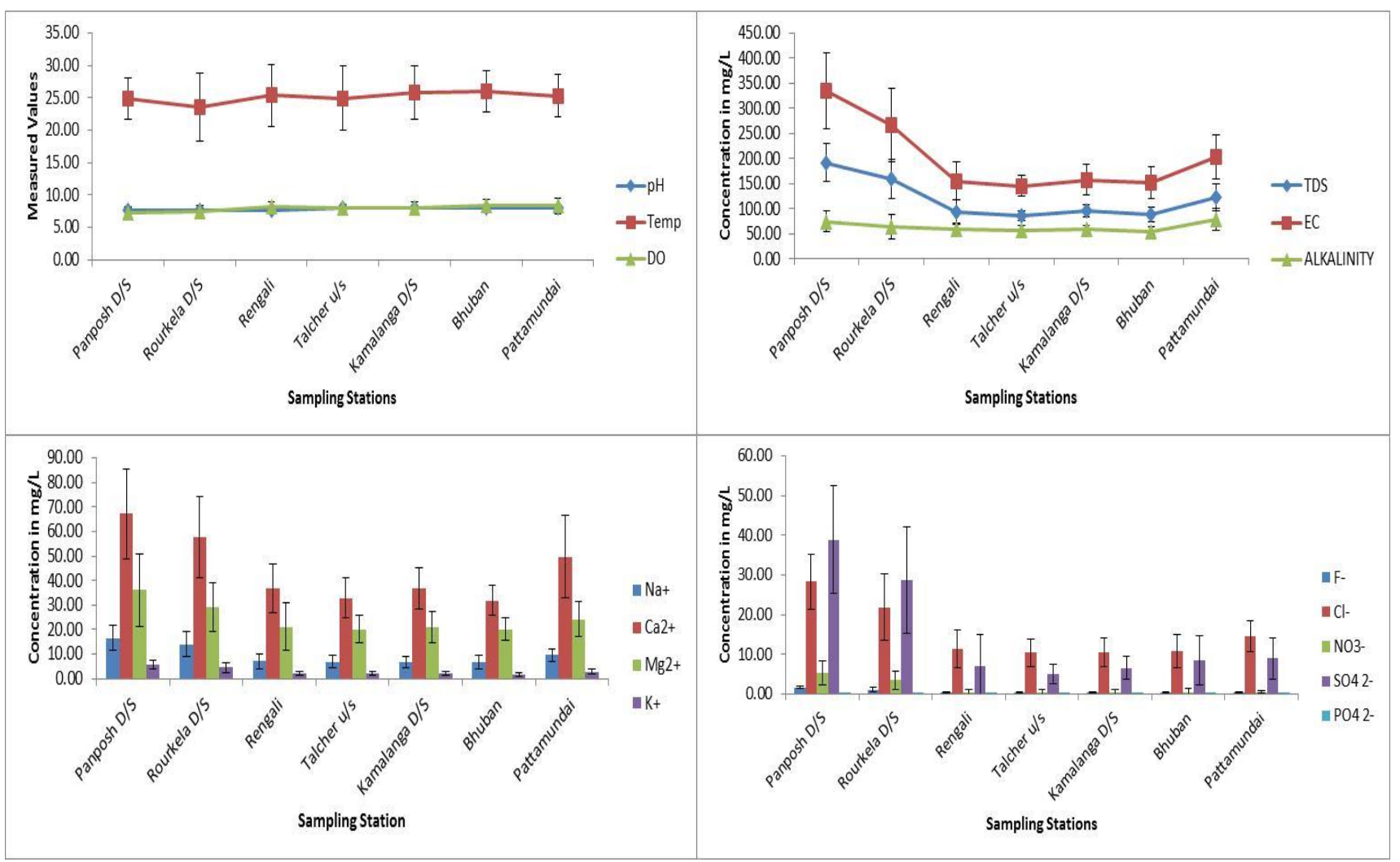

Fig. 2.Trend of physicochemical parameters along the sampling stations (S).

\subsubsection{Monsoon season}

The pH values of water of Brahmani ranges from 7.51 to 7.84 depending on the location. The $\mathrm{pH}$ values are within desired limits i.e., 6.5-8.5. $\mathrm{pH}$ value is good for plankton growth. The measured values of DO in Brahmani River for monsoon season were found in the range 6.63 to $7.53 \mathrm{mg} / \mathrm{L}$. DO is highest at Rengali and lowest at Panposh D/S. The Dissolved oxygen in the water is lower than the permissible limit of $8 \mathrm{mg} / \mathrm{L}$ for good quality drinking water by $\mathrm{K}$. Jyotivenkatchalam et al (2010).Temperature ranges from 26.67 to $28.67{ }^{\circ} \mathrm{C}$ over the different sampling stations of Brahmani River. The highest temperature is recorded at Kamalanga D/S and lowest at Rourkela D/S.The TDS value was found to be from 80.67 to $121.75 \mathrm{mg} / \mathrm{L}$ which is within the desirable limit (BIS, $500 \mathrm{mg} / \mathrm{L}$ ) and recorded highest at Panposh D/S. The values of EC reflected good quality of water at these locations, as the values are below the desirable limit.Alkalinity of Brahmani river at designated sampling stations were found in the range $44.17-57.67 \mathrm{mg} / \mathrm{L}$ and highest at Rourkela D/S. These values are within desirable limits suggested by BIS (200 mg/L). Major cations concentration at each sampling station showed the decreasing trend which followed the order as $\mathbf{C a}^{2+}>$ $\mathbf{M g}^{2+}>\mathrm{Na}^{+}>\mathrm{K}^{+}$. The major cations concentration along the sampling station is within the desirable limit.In the water of Brahmani River, $\mathbf{F}^{-}$ions were found in range $0.22 \mathrm{mg} / \mathrm{L}$ to 0.53 
$\mathrm{mg} / \mathrm{L}$ where sites Bhuban and Panposh D/S recorded lowest and highest values respectively. The concentration of $\mathbf{N O}_{3}{ }^{-}, \mathbf{S O}_{4}{ }^{2-}$ and $\mathbf{P O}_{4}{ }^{2-}$ were found in the range $0.63 \mathrm{mg} / \mathrm{L}$ to $1.83 \mathrm{mg} / \mathrm{L}, 10.20 \mathrm{mg} / \mathrm{L}$ to $23.19 \mathrm{mg} / \mathrm{L}$ and $0.04 \mathrm{mg} / \mathrm{L}$ to $0.24 \mathrm{mg} / \mathrm{L}$ respectively. The concentration trend was found as $\mathbf{S O}_{4}{ }^{2-}>\mathbf{C l}^{-}>\mathbf{N O}_{3}{ }^{-}>\mathbf{F}^{-}>\mathbf{P O}_{4}{ }^{2-}$ along all stations except Pattamundai where $\mathrm{Cl}^{-}>\mathrm{SO}_{4}{ }^{2-}$. This may be due to leaching from minerals, from rocks, and from saline deposit and may be attributed due to municipal wastes (Nikanorov et al. 2009).. All major anions are within the desirable limit in monsoon season. The trends of all the parameter along the sampling stations is shown in Fig. 3.

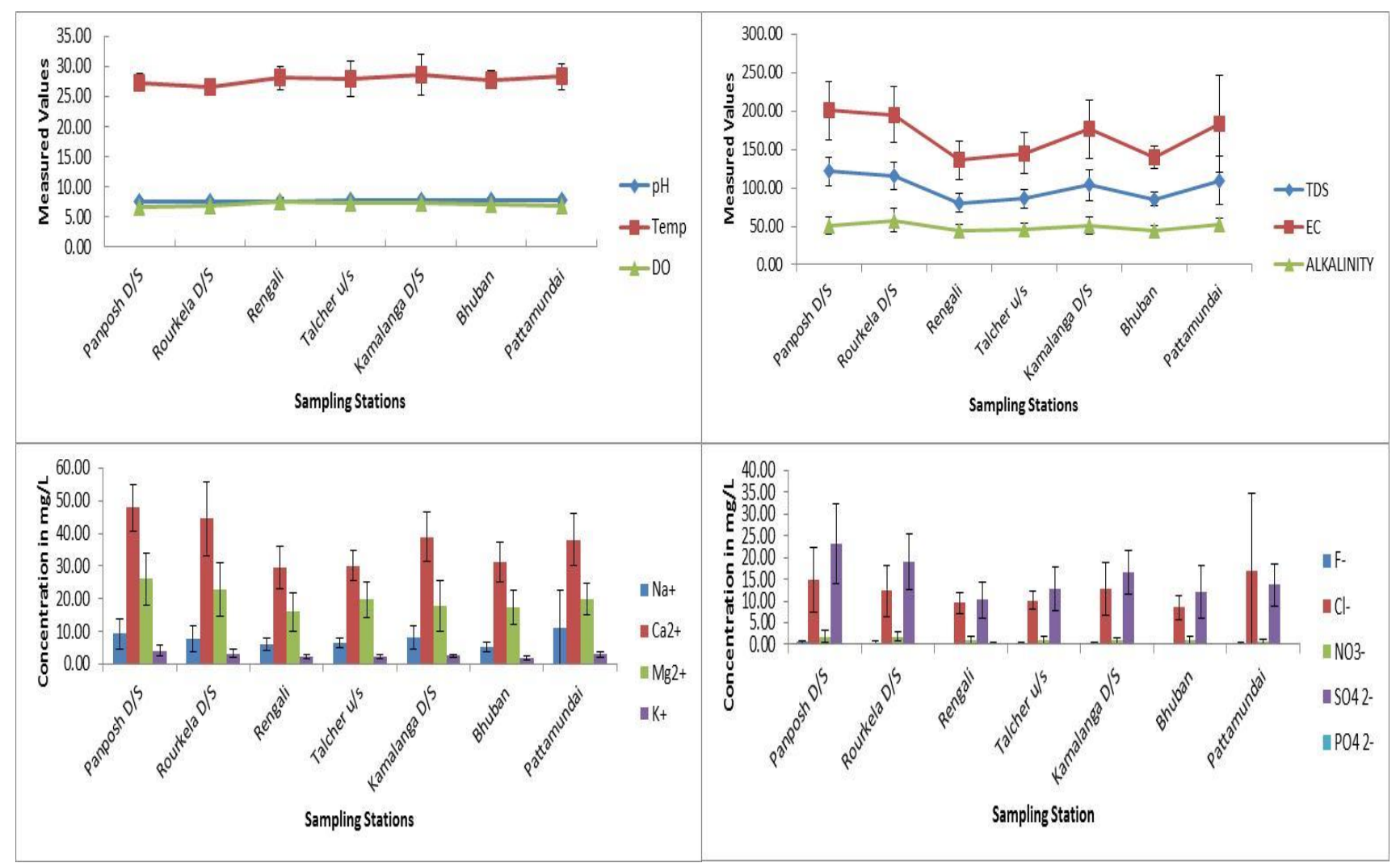

Fig. 3.Trend of physicochemical parameters along the sampling stations (M).

\subsubsection{Winter season}

ThepH values of water of Brahmani ranges from 7.63 to 8.01 depending on the location. The measured values of DO in Brahmani river for winter season were found in the range 7.18 to $8.33 \mathrm{mg} / \mathrm{L}$, maximum at Pattamundai and minimum at Panposh D/S. Temperature ranges from 23.50 to $26.0{ }^{\circ} \mathrm{C}$ over the different sampling stations of Brahmani river. The highest temperature is recorded at Bhuban and lowest at Rourkela D/S. The TDS value was found to be from 79.81 to $180.41 \mathrm{mg} / \mathrm{L}$ which is within the desirable limit (BIS, $500 \mathrm{mg} / \mathrm{L}$ ) and EC reflected good quality of water at these locations. Alkalinity of Brahmani river at designated 
sampling stations were found in the range $54.0-78.47 \mathrm{mg} / \mathrm{L}$, highest at Pattamundai. Major cations concentration at each sampling station showed the decreasing trend which followed the order as $\mathbf{C a}^{2+}>\mathbf{M g}^{2+}>\mathrm{Na}^{+}>\mathbf{K}^{+}$. All the concentration of the major cations are within desirable limit except $\mathbf{M g}^{2+}$ at Panposh D/S and Rourkela D/S which exceeds desirable limit (BIS, 30 $\mathrm{mg} / \mathrm{L}$ ). The reason for increase in $\mathbf{M g}^{2+}$ is same as in summer season.In the water of Brahmani River, $\mathbf{F}^{-}$ions were found in range $0.28 \mathrm{mg} / \mathrm{L}$ to $1.15 \mathrm{mg} / \mathrm{L}$ where site Panposh D/S value is more than the desirable limit (BIS, $1 \mathrm{mg} / \mathrm{L}$ ). The concentration of $\mathrm{NO}_{3}{ }^{-}, \mathbf{S O}_{4}{ }^{2-}$ and $\mathbf{P O}_{4}{ }^{2-}$ were found in the range $0.43 \mathrm{mg} / \mathrm{L}$ to $4.44 \mathrm{mg} / \mathrm{L}, 4.54 \mathrm{mg} / \mathrm{L}$ to $33.04 \mathrm{mg} / \mathrm{L}$ and 0.04 $\mathrm{mg} / \mathrm{L}$ to $0.09 \mathrm{mg} / \mathrm{L}$ respectively. The concentration of $\mathbf{N O}_{3}{ }^{-}$and $\mathbf{S O}_{4}{ }^{2-}, \mathbf{P O}_{4}{ }^{2-}$ were found to be within desirable limit. The $\mathbf{S O}_{4}{ }^{2-}$ concentration is more at Panposh $\mathrm{D} / \mathrm{S}$ and Rourkela D/S with respect to other anions. This may be due to industrial and waste water discharge into the river and presence of sedimentary rocks which include gypsum and anhydride (Nikanorov et al. 2009).The trends of all the parameter along the sampling stations is shown in Fig. 4.

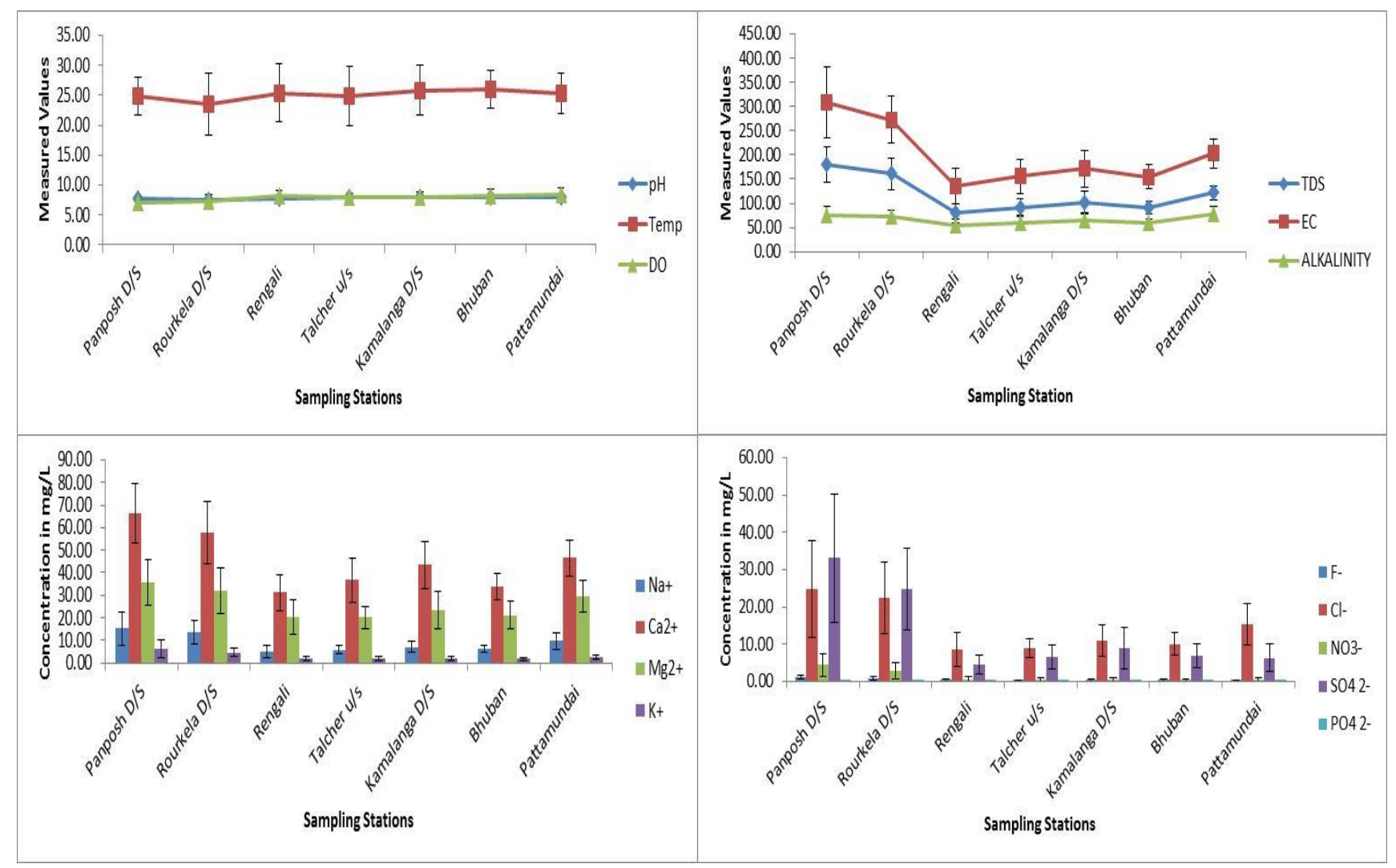

Fig. 4.Trend of physicochemical parameters along the sampling stations (W). 


\subsection{Statistical study of the Brahmani River}

\subsubsection{Descriptive Statistics Study}

Statistical summary of water samples in summer, monsoon and winter of Brahmani River for the year 2011, 2012, 2013, 2014, 2015is shown in Table 2. For the Brahmani River water, water is slightly alkaline in all the three seasons with mean $\mathbf{p H}$ of 7.85, 7.65 and 7.84 for summer, monsoon and winter respectively. The $\mathrm{pH}$ of the study area is slightly alkaline.The $\mathrm{pH}$ values between 6.5 and 8.5 were reported acceptable for outdoor bathing which is considered safe for the skin and delicate organs like eyes, nose, ears (CPCB,2009). The DO concentration with average values as 7.19, 7.08, and 7.91mg/L for summer, monsoon and winter season respectively. It is suitable for fishery.The Dissolved oxygen in the water is lower than the permissible limit of $8 \mathrm{mg} / \mathrm{L}$ for good quality drinking water by $\mathrm{K}$. Jyotivenkatchalam et al (2010). The temperature of the river in summer has an average of $31.3^{\circ} \mathrm{C}, 27.8^{\circ} \mathrm{C}$ in monsoon and $25.1^{\circ} \mathrm{C}$ in winter season. The TDS concentration is within the desirable limit with a mean of $119.82 \mathrm{mg} / \mathrm{L}, 100.30 \mathrm{mg} / \mathrm{L}, 117.79 \mathrm{mg} / \mathrm{L}$ for summer, monsoon and winter respectively. The TDS decrease is due to dilution in monsoon season. TDS increase in wintermay be due to deposition of sediment load transported from the watershed during the rainy season.Electrical conductivity showing mean as $202.36 \mu \mathrm{S} / \mathrm{cm}$, $168.26 \mu \mathrm{S} / \mathrm{cm}, 199.74 \mu \mathrm{S} / \mathrm{cmand}$ alkalinity as $63.94 \mathrm{mg} / \mathrm{L}, 49.52 \mathrm{mg} / \mathrm{L}, 65.93 \mathrm{mg} / \mathrm{L}$ in summer, monsoon and winter respectively which are within desirable limit. The EC increase is due to increase in dissolved ions. The concentration of major cations are in the order of $\mathbf{C a}^{2+}>\mathbf{M g}^{2+}>\mathbf{N a}^{+}>\mathbf{K}^{+}$in summer, monsoon and winter with mean values as $44.69 \mathrm{mg} / \mathrm{L}, 24.48$ $\mathrm{mg} / \mathrm{L}, 9.65 \mathrm{mg} / \mathrm{L}$ and $2.99 \mathrm{mg} / \mathrm{L}$ respectively for summer, $37.19 \mathrm{mg} / \mathrm{L}, 19.95 \mathrm{mg} / \mathrm{L}, 7.68$ $\mathrm{mg} / \mathrm{L}$ and $2.71 \mathrm{mg} / \mathrm{L}$ respectively for monsoon and $45.20 \mathrm{mg} / \mathrm{L}, 25.98 \mathrm{mg} / \mathrm{L}, 8.90 \mathrm{mg} / \mathrm{L}$ and $2.94 \mathrm{mg} / \mathrm{L}$ respectively for winter. All the measured cations are within the desirable limit. The concentration of major anions in summer are in the order of $\mathrm{Cl}^{-}>\mathbf{S O}_{4}^{2-}>\mathbf{N O}_{3}^{-}>\mathbf{F}^{-}>\mathbf{P O}_{4}^{3-}$ with mean values as $15.39 \mathrm{mg} / \mathrm{L}, 14.79 \mathrm{mg} / \mathrm{L}, 1.63 \mathrm{mg} / \mathrm{L}, 0.65 \mathrm{mg} / \mathrm{L}$ and $0.12 \mathrm{mg} / \mathrm{L}$ respectively. All the measured anions are within the desirable limit except $\mathbf{P O}_{\mathbf{4}}^{3-}$ which has received a maximum of $1.77 \mathrm{mg} / \mathrm{L}$ in summer season. The concentration of major anions in monsoon are in the order of $\mathbf{S O}_{4}^{2-}>\mathbf{C l}>\mathbf{N O}_{3}^{-}>\mathbf{F}^{-}>\mathbf{P O}_{4}^{3-}$ with mean values as $15.37 \mathrm{mg} / \mathrm{L}$, $12.14 \mathrm{mg} / \mathrm{L}, 1.16 \mathrm{mg} / \mathrm{L}, 0.33 \mathrm{mg} / \mathrm{L}$ and $0.09 \mathrm{mg} / \mathrm{L}$ respectively. All the measured anions are within the desirable limit and are lower than summer season except $\mathbf{S O}_{4}{ }^{2-}$. The increase in $\mathbf{S O}_{4}{ }^{2-}$ concentration is due to acid rain in monsoon season. The concentration of major anions 
in winter are in the order of $\mathbf{C l}^{-}>\mathbf{S O}_{4}{ }^{2-}>\mathbf{N O}_{3}^{-}>\mathbf{F}^{-}>\mathbf{P O}_{4}^{3-}$ with mean values as $14.31 \mathrm{mg} / \mathrm{L}$, $12.97 \mathrm{mg} / \mathrm{L}, 1.38 \mathrm{mg} / \mathrm{L}, 0.50 \mathrm{mg} / \mathrm{L}$ and $0.061 \mathrm{mg} / \mathrm{L}$ respectively. All the measured anions are within the desirable limit and there is an increase in $\mathbf{C l}^{-i o n}$ and decrease in $\mathbf{S O}_{4}{ }^{2 \text {-ion }}$ w.r.t monsoon.

\subsubsection{Correlation and Regression Analysis}

The correlation coefficients (r) among various waterquality parameters of surface water of the study area in summer, monsoon and winter season were calculatedand the values of correlation coefficients (r) are given in Table 3, 4 and 5 respectively.In summer season (Table 3), $\mathrm{pH}$ has a moderate negative correlation with $\mathrm{SO}_{4}^{2-}(\mathrm{r}=-.545)$ and has poor correlation with other parameters. It indicates that water is alkaline in nature. TDS has a strong positive correlation with EC $(\mathrm{r}=.969), \mathrm{Na}^{+}(\mathrm{r}=.841), \mathrm{Ca}^{2+}(\mathrm{r}=.898), \mathrm{K}^{+}(\mathrm{r}=.82), \mathrm{Cl}^{-}$ $(\mathrm{r}=.889), \mathrm{SO}_{4}^{2-}(\mathrm{r}=.865)$ and moderate positive correlation with alkalinity $(\mathrm{r}=.551), \mathrm{Mg}^{+}$ $(\mathrm{r}=.572), \mathrm{F}^{-}(\mathrm{r}=.768)$, and $\mathrm{NO}_{3}^{-}(\mathrm{r}=.708)$. This indicates that these ions contribute major part to the TDS of the water. There is a moderate positive correlation between alkalinity-Ca ${ }^{2+}$ $(\mathrm{r}=.622)$ and alkalinity- $\mathrm{Mg}^{2+}(\mathrm{r}=.531)$. EC has significant positive correlation with the $\mathrm{Na}^{+}(\mathrm{r}$ $=.843), \mathrm{Ca}^{2+}(\mathrm{r}=.865), \mathrm{Cl}^{-}(\mathrm{r}=.884), \mathrm{SO}_{4}^{2-}(\mathrm{r}=.884)$ and moderate positive correlation with $\mathrm{Mg}^{+}(\mathrm{r}=.550), \mathrm{K}^{+}(\mathrm{r}=.781), \mathrm{F}^{-}(\mathrm{r}=.765)$ and $\mathrm{NO}_{3}^{-}(\mathrm{r}=.697)$. This shows that these ions play major part in contributing conductance to the water. Sodium ions are well known for raising conductivity and decreasing soil permeability. $\mathrm{Na}^{+}$has high positive correlation with chloride $(\mathrm{r}=.922)$ and has a moderate positive relation with $\mathrm{Ca}^{2+}(\mathrm{r}=.696), \mathrm{K}^{+}(\mathrm{r}=.748), \mathrm{F}^{-}(\mathrm{r}=.725)$, $\mathrm{NO}_{3}^{-}(\mathrm{r}=.645)$ and $\mathrm{SO}_{4}^{2-}(\mathrm{r}=.767)$. The $\mathrm{Na}^{+}$and $\mathrm{Cl}^{-}$high correlation suggest that there might be discharge of $\mathrm{NaCl}$ from domestic sewage and imparts salinity to water.Already it is mentioned that there is significant positive relation between $\mathrm{Ca}^{2+}$-TDS and $\mathrm{Ca}^{2+}-\mathrm{EC}$. It is seen that $\mathrm{Ca}^{2+}$ has a moderate positive relation with $\mathrm{K}^{+}(\mathrm{r}=.702), \mathrm{F}^{-}(\mathrm{r}=.618), \mathrm{Cl}^{-}(\mathrm{r}=.724)$, $\mathrm{SO}_{4}^{2-}(\mathrm{r}=.739)$, and $\mathrm{NO}_{3}^{-}(\mathrm{r}=.567) \cdot \mathrm{Mg}^{2+}$ has moderate positive relationship with $\mathrm{SO}_{4}^{2-}(\mathrm{r}$ $=.551)$, TDS, EC as described above. $\mathrm{K}^{+}$has a positive correlation with $\mathrm{F}^{-}(\mathrm{r}=.739), \mathrm{Cl}^{-}(\mathrm{r}$ $=.792), \mathrm{SO}_{4}^{2-}(\mathrm{r}=.797), \mathrm{NO}_{3}^{-}(\mathrm{r}=.637)$ as well as with TDS, EC, $\mathrm{Na}^{+}, \mathrm{Ca}^{2+}$. F-is correlated $(0.74<\mathrm{r}<0.77)$ with $\mathrm{Cl}^{-}, \mathrm{NO}_{3}^{-}, \mathrm{SO}_{4}^{2-}$ and with $\mathrm{K}^{+}, \mathrm{EC}$, and TDS. The correlation between $\mathrm{NO}_{3}^{-}$and $\mathrm{SO}_{4}^{2-}(\mathrm{r}=.692)$ is positive with reasonable significance. 
1 Table 2.Statistical summary of physicochemical parameters.

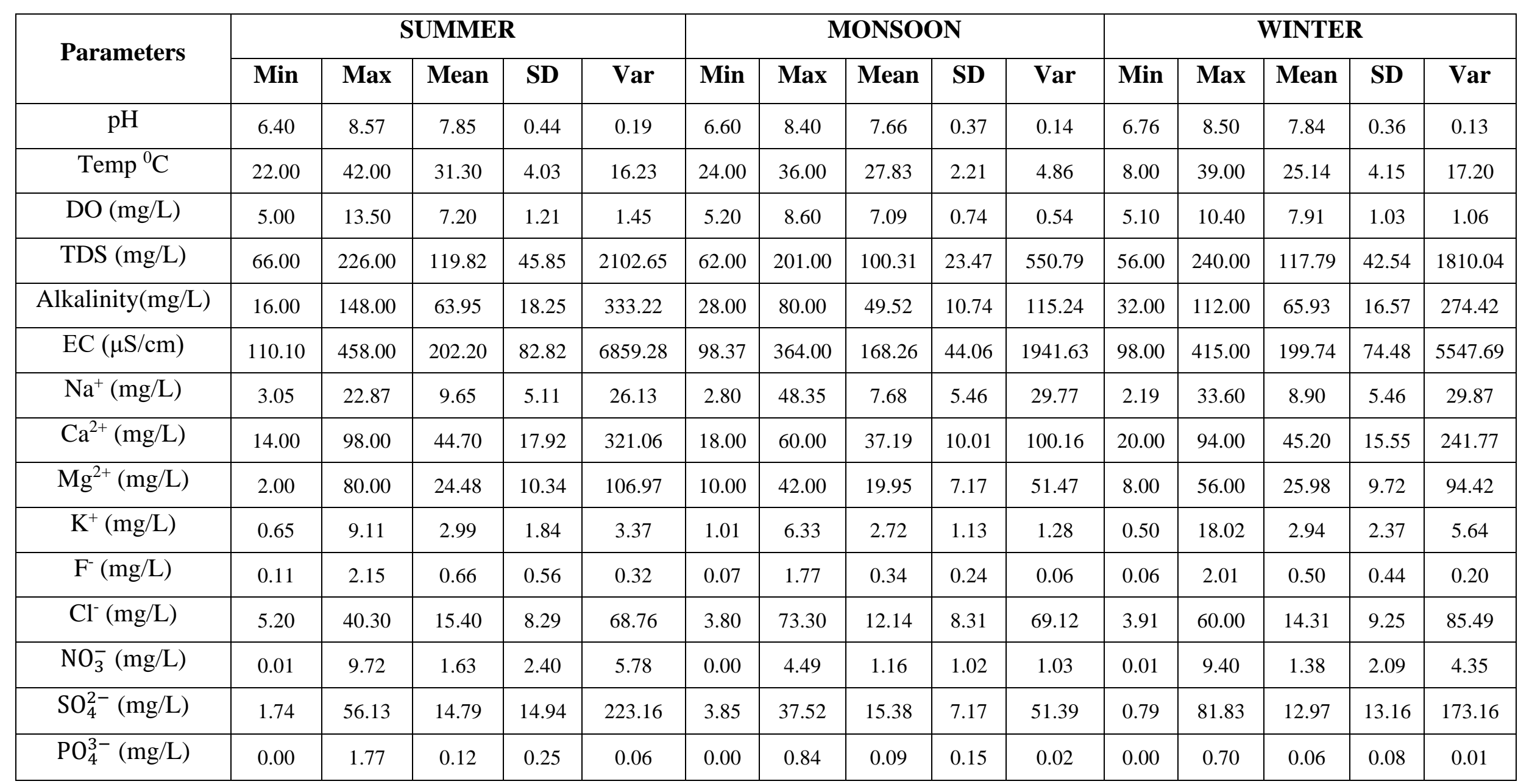

2 Max-Maximum,Min-Minimum,SD-StandardDeviation, Var-variance

3 Table 3Correlation coefficients (r) among various water quality parameters in summer. 


\begin{tabular}{|c|c|c|c|c|c|c|c|c|c|c|c|c|c|c|c|}
\hline Parameters & $\mathrm{pH}$ & Temp & DO & TDS & Alkalinity & EC & $\mathrm{Na}^{+}$ & $\mathrm{Ca}^{2+}$ & $\mathrm{Mg}^{2+}$ & $\mathrm{K}^{+}$ & $\mathrm{F}^{-}$ & $\mathrm{Cl}^{-}$ & $\mathrm{NO}_{3}^{-}$ & $\mathrm{SO}_{4}^{2-}$ & $\mathrm{PO}_{4}^{3-}$ \\
\hline $\mathrm{pH}$ & 1 & & & & & & & & & & & & & & \\
\hline Temp & $.217^{*}$ & 1 & & & & & & & & & & & & & \\
\hline DO & $.207 *$ & $.210^{*}$ & 1 & & & & & & & & & & & & \\
\hline TDS & $-.384^{* *}$ & $-.347^{* *}$ & $-.256 * *$ & 1 & & & & & & & & & & & \\
\hline Alkalinity & 0.065 & $-.214^{*}$ & $-.210^{*}$ & $.551^{* *}$ & 1 & & & & & & & & & & \\
\hline $\mathrm{EC}$ & $-.406 * *$ & $-.308^{* *}$ & $-.253^{* *}$ & $.969 * *$ & $.461 * *$ & 1 & & & & & & & & & \\
\hline $\mathrm{Na}^{+}$ & $-.316 * *$ & $-.313 * *$ & -0.162 & $.841 * *$ & $.283^{* *}$ & $.843^{* *}$ & 1 & & & & & & & & \\
\hline $\mathrm{Ca}^{2+}$ & $-.296 * *$ & $-.339 * *$ & $-.240 *$ & $.898^{* *}$ & $.622^{* *}$ & $.865^{* *}$ & $.696^{* *}$ & 1 & & & & & & & \\
\hline $\mathrm{Mg}^{2+}$ & $-.300 * *$ & $-.328 * *$ & -0.165 & $.572^{* *}$ & $.531 * *$ & $.550 * *$ & $.373^{* *}$ & $.449 * *$ & 1 & & & & & & \\
\hline $\mathrm{K}^{+}$ & $-.461^{* *}$ & $-.407^{* *}$ & $-.274 * *$ & $.820^{* *}$ & $.266^{* *}$ & $.781 * *$ & $.748 * *$ & $.702 * *$ & $.410 * *$ & 1 & & & & & \\
\hline $\mathrm{F}^{-}$ & $-.409 * *$ & $-.262^{* *}$ & $-.240^{*}$ & $.768^{* *}$ & $.252^{* *}$ & $.765^{* *}$ & $.725^{* *}$ & $.618^{* *}$ & $.492^{* *}$ & $.739 * *$ & 1 & & & & \\
\hline $\mathrm{Cl}^{-}$ & $-.382^{* *}$ & $-.340 * *$ & $-.206^{*}$ & $.889 * *$ & $.333^{* *}$ & $.884 * *$ & $.922^{* *}$ & $.724 * *$ & $.458^{* *}$ & $.792 * *$ & $.771 * *$ & 1 & & & \\
\hline $\mathrm{NO}_{3}^{-}$ & $-.489 * *$ & -0.109 & -0.092 & $.708^{* *}$ & 0.103 & $.697^{* *}$ & $.645^{* *}$ & $.567^{* *}$ & $.323^{* *}$ & $.637^{* *}$ & $.742 * *$ & $.719 * *$ & 1 & & \\
\hline $\mathrm{SO}_{4}^{2-}$ & $-.545^{* *}$ & $-.369 * *$ & $-.274^{* *}$ & $.865^{* *}$ & $.188^{*}$ & $.884^{* *}$ & $.767^{* *}$ & $.739 * *$ & $.551 * *$ & $.797^{* *}$ & $.757 * *$ & $.790 * *$ & $.692 * *$ & 1 & \\
\hline $\mathrm{PO}_{4}^{3-}$ & -0.065 & 0.009 & $.297 * *$ & $.226 *$ & -0.009 & $.230 *$ & $.282^{* *}$ & 0.12 & 0.119 & 0.13 & $.286^{* *}$ & $.262 * *$ & $.297^{* *}$ & $.204 *$ & 1 \\
\hline
\end{tabular}

5

$8 \mathrm{~N}=110$.

\footnotetext{
$8+110$.$$
\text { . }
$$

\footnotetext{
$6 *$ Correlation is significant at the 0.05 level (2-tailed).

$7 * *$ Correlation is significant at the 0.01 level (2-tailed).
} 
9 In monsoon season (Table 4),EC has strong positive correlation with TDS $(\mathrm{r}=.975) . \mathrm{Na}^{+}$, $10 \mathrm{Ca}^{2+}, \mathrm{K}^{+}, \mathrm{Cl}^{-}$and $\mathrm{SO}_{4}{ }^{2-}$ has moderate positive relationship with TDS $(.61<\mathrm{r}<.67)$ and EC $11(.58<\mathrm{r}<.64)$. We can interpret here that these ions have more influence on TDS than EC. 12 The correlation between $\mathrm{Na}^{+}$and $\mathrm{Cl}^{-}$is seen very strong $(\mathrm{r}=.985) . \mathrm{SO}_{4}{ }^{2-}$ is seen having 13 moderate positive relation with $\mathrm{Ca}^{2+}, \mathrm{K}^{+}$and $\mathrm{NO}_{3}{ }^{-}(.53<\mathrm{r}<.59)$. The other water quality 14 parameters are weakly correlated with each other and are shown in Table 5.

15 In winter season (Table 5), EC has strong positive correlation with TDS $(\mathrm{r}=.980) . \mathrm{Ca}^{2+}$ too 16 has a strong positive correlation with the TDS $(\mathrm{r}=.903) . \mathrm{Na}^{+}, \mathrm{Cl}^{-}$and $\mathrm{SO}_{4}{ }^{2-}$ has good positive 17 correlation with $\operatorname{TDS}(.81<\mathrm{r}<.86)$. Alkalinity, $\mathrm{Mg}^{2+}, \mathrm{K}^{+}, \mathrm{F}^{-}, \mathrm{NO}_{3}^{-}$has shown moderate 18 positive correlation with TDS $(.61<\mathrm{r}<.76)$. This indicates that the mentioned ions contribute 19 to the TDS. EC has strong positive correlation with $\mathrm{Na}^{+}, \mathrm{Ca}^{2+}, \mathrm{Cl}^{-}, \mathrm{SO}_{4}{ }^{2-}(.80<\mathrm{r}<.87)$ and 20 has moderate positive correlation with $\mathrm{NO}_{3}^{-}, \mathrm{F}^{-}, \mathrm{K}^{+}$and $\mathrm{Mg}^{2+}$. This shows that these ions play 21 major part in contributing conductance to the water. $\mathrm{Na}^{+}$has a strong positive correlation 22 with $\mathrm{Cl}^{-}(\mathrm{r}=.97)$ and $\mathrm{K}^{+}(\mathrm{r}=.80)$. $\mathrm{Na}^{+}$has a moderate positive correlation with $\mathrm{Ca}^{2+}, \mathrm{F}^{-}, \mathrm{NO}_{3}^{-}$. 
Table 4Correlation coefficients (r) among various water quality parameters in monsoon.

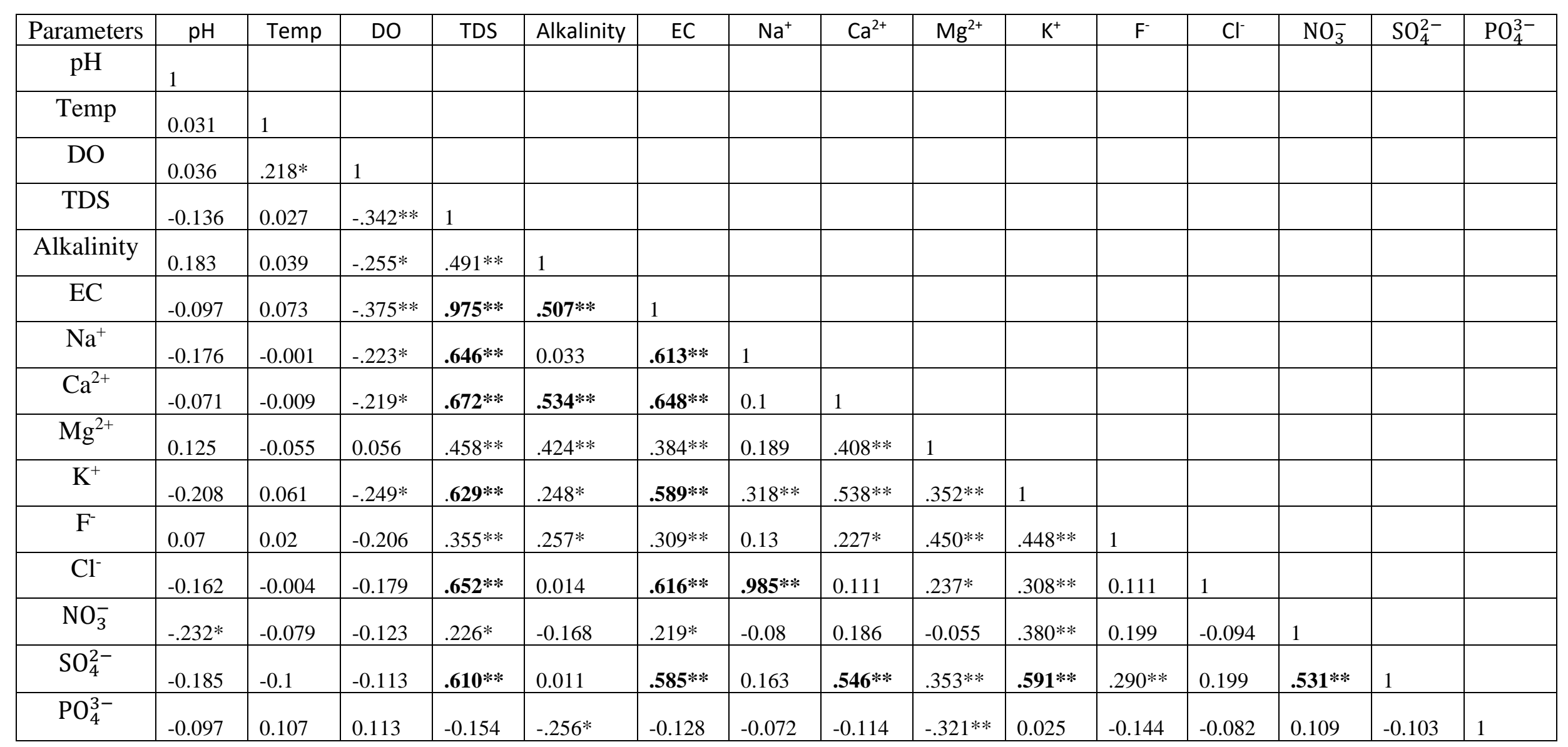

* Correlation is significant at the 0.05 level (2-tailed).

** Correlation is significant at the 0.01 level (2-tailed).

$\mathrm{N}=84$. 
Table 5Correlation coefficients (r) among various water quality parameters in winter.

\begin{tabular}{|c|c|c|c|c|c|c|c|c|c|c|c|c|c|c|c|}
\hline Parameters & $\mathrm{pH}$ & Temp & DO & TDS & Alkalinity & $\mathrm{EC}$ & $\mathrm{Na}^{+}$ & $\mathrm{Ca}^{2+}$ & $\mathrm{Mg}^{2+}$ & $\mathrm{K}^{+}$ & $\mathrm{F}^{-}$ & $\mathrm{Cl}^{-}$ & $\mathrm{NO}_{3}^{-}$ & $\mathrm{SO}_{4}^{2-}$ & $\mathrm{PO}_{4}^{3-}$ \\
\hline $\mathrm{pH}$ & 1 & & & & & & & & & & & & & & \\
\hline Temp & 0.09 & 1 & & & & & & & & & & & & & \\
\hline $\mathrm{DO}$ & $.239 *$ & -0.01 & 1 & & & & & & & & & & & & \\
\hline TDS & $-.247 * *$ & $-.189 *$ & $-.299 * *$ & 1 & & & & & & & & & & & \\
\hline Alkalinity & 0.027 & $-.196 *$ & -0.037 & $.669 * *$ & 1 & & & & & & & & & & \\
\hline $\mathrm{EC}$ & $-.273 * *$ & $-.188 *$ & $-.285 * *$ & $.980 * *$ & $.623 * *$ & 1 & & & & & & & & & \\
\hline $\mathrm{Na}^{+}$ & $-.209 *$ & -0.082 & $-.236 *$ & $.860 * *$ & $.490 * *$ & $.838 * *$ & 1 & & & & & & & & \\
\hline $\mathrm{Ca}^{2+}$ & -0.134 & -0.139 & $-.262 * *$ & $.903 * *$ & $.714 * *$ & $.879 * *$ & $.691 * *$ & 1 & & & & & & & \\
\hline $\mathrm{Mg}^{2+}$ & -0.14 & $-.234 *$ & $-.193 *$ & $.674 * *$ & $.690 * *$ & $.658 * *$ & $.463 * *$ & $.593 * *$ & 1 & & & & & & \\
\hline $\mathrm{K}^{+}$ & $-.232 *$ & -0.048 & $-.311 * *$ & $.728 * *$ & $.300 * *$ & $.722 * *$ & $.808 * *$ & $.546 * *$ & $.452 * *$ & 1 & & & & & \\
\hline $\mathrm{F}^{-}$ & $-.303 * *$ & $-.186 *$ & $-.301 * *$ & $.769 * *$ & $.322 * *$ & $.776 * *$ & $.717 * *$ & $.653 * *$ & $.416 * *$ & $.721 * *$ & 1 & & & & \\
\hline $\mathrm{Cl}^{-}$ & $-.221 *$ & -0.063 & $-.201 *$ & $.826 * *$ & $.473 * *$ & $.803 * *$ & $.978 * *$ & $.638 * *$ & $.440 * *$ & $.819 * *$ & $.679 * *$ & 1 & & & \\
\hline $\mathrm{NO}_{3}^{-}$ & $-.227 *$ & -0.122 & $-.277 * *$ & $.613 * *$ & $.218 *$ & $.594 * *$ & $.592 * *$ & $.515 * *$ & $.277 * *$ & $.665 * *$ & $.714 * *$ & $.548 * *$ & 1 & & \\
\hline $\mathrm{SO}_{4}^{2-}$ & $-.319 * *$ & -0.176 & $-.316^{* *}$ & $.810 * *$ & $.296 * *$ & $.827 * *$ & $.589 * *$ & $.738 * *$ & $.511 * *$ & $.552 * *$ & $.752 * *$ & $.531 * *$ & $.518^{* * *}$ & 1 & \\
\hline $\mathrm{PO}_{4}^{3-}$ & 0.057 & $-.216^{*}$ & -0.172 & -0.033 & -0.095 & -0.02 & -0.084 & -0.061 & -0.056 & -0.004 & 0.04 & -0.077 & 0.061 & 0.01 & 1 \\
\hline
\end{tabular}

* Correlation is significant at the 0.05 level (2-tailed).

** Correlation is significant at the 0.01 level (2-tailed).

$\mathrm{N}=112$ 
$\mathrm{SO}_{4}{ }^{2-}(.58<\mathrm{r}<.71) . \mathrm{Ca}^{2+}$ has moderate positive correlation with $\mathrm{Mg}^{2+}, \mathrm{K}^{+}, \mathrm{F}^{-}, \mathrm{Cl}^{--}, \mathrm{NO}_{3}^{-}$, $\mathrm{SO}_{4}{ }^{2-}(.51<\mathrm{r}<.73) . \mathrm{K}^{+}$has a strong positive correlation with $\mathrm{Cl}^{-}(\mathrm{r}=.81)$ and moderate correlation with $\mathrm{SO}_{4}{ }^{2-}, \mathrm{NO}_{3}^{-}$, and $\mathrm{F}^{-}$. The strong correlation between $\mathrm{K}^{+}$and $\mathrm{Cl}^{-}$means the presence of $\mathrm{KCl}$ which is not significantly seen in summer and monsoon. The correlation between $\mathrm{F}^{-}, \mathrm{Cl}^{-}, \mathrm{NO}_{3}^{-}, \mathrm{SO}_{4}{ }^{2-}$ is found to be moderate $(.51<\mathrm{r}<.75)$.

The linear regression analysis has been carried out for the water quality parameters which were found to have better and higher level of significance in their correlation coefficient. The regression analysis equations for the summer, monsoon and winter are given in Table 6.

\subsection{WQI of Brahmani River along Sampling stations}

From Table 7, it can be concluded that all the sampling stations in monsoon from 2011 to 2015, water quality index is found to be good within the WQI range 26-50, but the ranges were varied from good to poor in summer and winter. It is concluded from the results that overall quality of water is good for use at the sampling sites in monsoon also in other seasons with some purification of water at Panposh D/S and Rourkela D/S. The fluctuation can be due to the industrial effluent discharge, sewage water disposal, agricultural waste disposal and other domestic effluents. The water quality index obtained for the Brahmani River in different seasons of study period i.e., summer season, monsoon season and winter season are 44.1, 36.7, 41.8 respectively which indicate the Good quality of water (Yadav et al. 2010). The water quality Index shows the seasonal variation of the given water quality parameters in Brahmani River. For the easy interpretation of the water quality index values with seasonal variation from 2011 to 2015 at seven selected gauging stations, the variation in WQI values are graphically shown in Fig. 5.

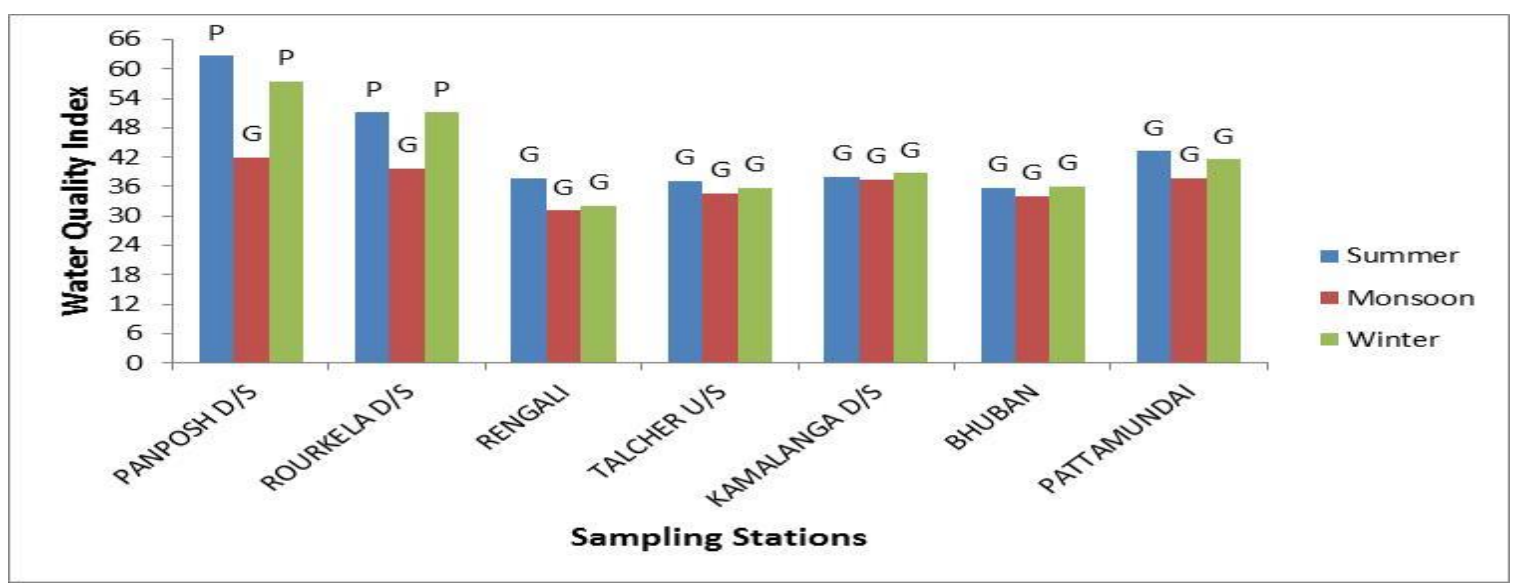

Fig. 5. WQI at sampling stations of Brahmani River 
Table 6Regression Equations for Surface Water Quality Parameters

\begin{tabular}{|c|c|c|c|c|c|}
\hline $\begin{array}{c}\widehat{y} \\
\text { (Dependent) }\end{array}$ & $\begin{array}{c}\mathbf{x} \\
\text { (Independent) }\end{array}$ & $\begin{array}{c}\text { R squared } \\
\text { value }\end{array}$ & bo & $\mathbf{b}_{1}$ & Regression Equation \\
\hline \multicolumn{6}{|c|}{ SUMMER SEASON } \\
\hline $\mathrm{Na}^{+}$ & TDS & 0.707 & -1.58 & 0.09 & $\mathrm{Na}^{+}=-1.58+0.09 *(\mathrm{TDS})$ \\
\hline $\mathrm{Ca}^{2+}$ & TDS & 0.808 & 2.6 & 0.35 & $\mathrm{Ca}^{2+}=2.67+0.35(\mathrm{TDS})$ \\
\hline $\mathrm{Cl}^{-}$ & TDS & 0.788 & -3.84 & 0.16 & $\mathrm{Cl}^{-}=-3.84+0.16(\mathrm{TDS})$ \\
\hline $\mathrm{SO}_{4}{ }^{2-}$ & TDS & 0.750 & -19.02 & 0.28 & $\mathrm{SO}_{4}{ }^{2-}=19.02+0.28(\mathrm{TDS})$ \\
\hline $\mathrm{EC}$ & TDS & 0.940 & -7.65 & 1.75 & $\mathrm{EC}=-7.65+1.75(\mathrm{TDS})$ \\
\hline $\mathrm{Na}^{+}$ & $\mathrm{EC}$ & 0.711 & -0.87 & 0.05 & $\mathrm{Na}^{+}=-0.87+0.05^{*}(\mathrm{EC})$ \\
\hline $\mathrm{Ca}^{2+}$ & $\mathrm{EC}$ & 0.760 & 6.81 & 0.19 & $\mathrm{Ca}^{2+}=6.81+0.19(\mathrm{EC})$ \\
\hline $\mathrm{Cl}^{-}$ & $\mathrm{EC}$ & 0.780 & -2.49 & 0.09 & $\mathrm{Cl}^{-}=-2.49+0.09(\mathrm{EC})$ \\
\hline $\mathrm{SO}_{4}{ }^{2-}$ & $\mathrm{EC}$ & 0.783 & -17.48 & 0.16 & $\mathrm{SO}_{4}{ }^{2-}=-17.48+0.16(\mathrm{EC})$ \\
\hline $\mathrm{Cl}^{-}$ & $\mathrm{Na}^{+}$ & 0.851 & 0.95 & 1.5 & $\mathrm{Cl}^{-}=0.95+1.5\left(\mathrm{Na}^{+}\right)$ \\
\hline \multicolumn{6}{|c|}{ MONSOON SEASON } \\
\hline TDS & $\mathrm{EC}$ & 0.95 & 12.939 & 0.519 & $\mathrm{TDS}=12.939+0.519 *(\mathrm{EC})$ \\
\hline $\mathrm{Cl}^{-}$ & $\mathrm{Na}^{+}$ & 0.97 & -0.167 & 0.646 & $\mathrm{Cl}^{-}=-0.167+0.646\left(\mathrm{Na}^{+}\right)$ \\
\hline \multicolumn{6}{|c|}{ WINTER SEASON } \\
\hline TDS & $\mathrm{EC}$ & 0.960 & 6.034 & 0.580 & $\mathrm{TDS}=6.034+0.58 *(\mathrm{EC})$ \\
\hline $\mathrm{Na}^{+}$ & TDS & 0.739 & -4.106 & 0.110 & $\mathrm{Na}^{+}=-4.106+0.11 *(\mathrm{TDS})$ \\
\hline $\mathrm{Ca}^{2+}$ & TDS & 0.814 & 6.368 & 0.330 & $\mathrm{Ca}^{2+}=-6.368+0.33^{*}(\mathrm{TDS})$ \\
\hline $\mathrm{Na}^{+}$ & $\mathrm{EC}$ & 0.701 & -3.367 & 0.061 & $\mathrm{Na}^{+}=-3.367+0.061 *(\mathrm{EC})$ \\
\hline $\mathrm{Ca}^{2+}$ & $\mathrm{EC}$ & 0.770 & 8.620 & 0.183 & $\mathrm{Ca}^{2+}=8.620+0.183 *(\mathrm{EC})$ \\
\hline $\mathrm{Na}^{+}$ & $\mathrm{Cl}^{-}$ & 0.954 & 0.643 & 0.577 & $\mathrm{Na}^{+}=0.643+0.577 *\left(\mathrm{Cl}^{-}\right)$ \\
\hline
\end{tabular}


Table 7Water Quality Index Values and Quality

\begin{tabular}{|c|c|c|c|c|c|c|}
\hline \multirow{2}{*}{ Station } & \multicolumn{2}{|c|}{ Summer } & \multicolumn{2}{c|}{ Monsoon } & \multicolumn{2}{c|}{ Winter } \\
\cline { 2 - 7 } & Index & Quality & Index & Quality & Index & Quality \\
\hline Panposh D/S & 62.8 & Poor & 41.9 & Good & 57.5 & Poor \\
\hline Rourkela D/S & 51.1 & Poor & 39.7 & Good & 51.1 & Poor \\
\hline Rengali & 37.6 & Good & 31.1 & Good & 32 & Good \\
\hline Talcher U/S & 37.2 & Good & 34.6 & Good & 35.8 & Good \\
\hline Kamalanga D/S & 37.9 & Good & 37.5 & Good & 38.7 & Good \\
\hline Bhuban & 35.8 & Good & 34.1 & Good & 35.9 & Good \\
\hline Pattamundai & 43.2 & Good & 37.7 & Good & 41.5 & Good \\
\hline BRAHMANI & 44.1 & Good & 36.7 & Good & 41.8 & Good \\
\hline
\end{tabular}

\section{Conclusion}

Results of correlation analysis show that TDS and EC shows high correlation with other parameters. Since TDS and EC gives high correlation with $\mathrm{Na}^{+}, \mathrm{Ca}^{2+}, \mathrm{Cl}^{-}$, and $\mathrm{SO}_{4}{ }^{2-}$, regression equation relating TDS, EC and these parameters have been formulated for summer, monsoon and winter season. Hence by making measurements of the TDS and EC, concentration of the better related parameters $\mathrm{Ca}^{2+}, \mathrm{Na}^{+}, \mathrm{Cl}^{-}$, and $\mathrm{SO}_{4}{ }^{2-}$ can be estimated. Indirect method of evaluation of surface water quality presented in this thesis provides a better alternative for a systematic study over the conventional technique. This may therefore treated as a rapid method of water quality monitoring for the Brahmani River.It is found that Panposh D/S and Rourkela D/S sampling stations are the principal monitoring stations having more impact on water quality, than other stations. The Water Quality Index (WQI) values for the sampling stations is good in monsoon season and vary from good to poor during summer and winter seasons. Panposh D/S and Rourkela D/S showed poor water quality in summer and winter. 


\section{References}

Abdul Hameed M Jawad, A., Haider S, A., \&Bahram K, M. (2010). Application of water quality index for assessment of Dokan lake ecosystem, Kurdistan region, Iraq. journal of water resource and protection, 2010.

Agarwal, A., \& Saxena, M. Assessment of pollution by physicochemical water parameters using regression analysis: a case study of Gaganriver at Moradabad-India. Advances in Applied Science Research,2(2), 185-189, 2011.

Agarwal, M., Agarwal, A. Linear Regression And Correlation Analysis Of Water Quality Parameters: A Case Study Of River Kosi at District Rampur, India. International Journal of Innovative Research in Science, Engineering and Technology, ISSN, 2319-8753, 2013.

Ahipathy, M. V., \&Puttaiah, E. T. Ecological characteristics of vrishabhavathy River in Bangalore (India). Environmental geology, 49(8), 1217-1222, 2006.

C.P.C.B., Central Pollution Control Board, 2009. Ministry of Environment and forest Ganga Water Quality Trend, Monitoring of Indian Aquatic Resources. Series: MINARS/31/20092010.

Chun, K. C., Chang, R. W., Williams, G. P., Chang, Y. S., Tomasko, D., LaGory, K., ... \& Lee, B. K. Water quality issues in the Nakdong River Basin in the Republic of Korea. Environmental Engineering and Policy,2(3), 131-143,1999.

Daraigan, S. G., Wahdain, A. S., Ba-Mosa, A. S., \&Obid, M. H.Linear correlation analysis study of drinking water quality data for Al-Mukalla City, Hadhramout, Yemen. International Journal of Environmental Sciences, 1(7), 1692,2011.

Das, J., \&Acharya, B. C...Hydrology and assessment of lotic water quality in Cuttack city, India. Water, Air, and Soil Pollution, 150(1-4), 163-175,2003.

Dash, J. R., Dash, P. C., \&Patra, H. K. A Correlation and Regression Study on the Ground Wa-ter Quality in Rural Areas AroundAngul-Talcher Indus-tfialZone, 2006.

Florence, P. L., Paulraj, A., Ramachandramoorthy, T. Water Quality Index and Correlation study for the assessment of water quality and its parameters of YercaudTaluk, Salem District, Tamil Nadu, India. Chemical Science Transactions, 1(1), 139-149,2012.

Hegde, G. R., \& Kale, Y. S. Quality of lentic waters of Dharwad district in North Karnataka. Indian Journal of Environmental Health, 37(1), 52-56,1995.

Heydari, M. M., Abbasi, A., Rohani, S. M., \&Hosseini, S. M. A..Correlation study and regression analysis of drinking water quality in Kashan City, Iran. Walailak Journal of Science and Technology (WJST), 10(3), 315-324,2013. 
Horton, R. K. An index number system for rating water quality.Journal of Water Pollution Control Federation, 37(3), 300-306,1965.

Huq, S. I., \&Alam, M. D..A handbook on analyses of soil, plant and water. BACER-DU, University of Dhaka, Bangladesh, 246,2005.

Indian Standard Specification for Drinking Water, Bureau of Indian Standards. BIS: 10500, (1991) (Second Revision)

Indian Standard Specification for Drinking Water, Bureau of Indian Standards. BIS: 10500, (2012)

Jain, C. K., \& Sharma, M. K. Regression analysis of ground water quality data of Malprabha river basin, Karnataka. J. Indian Water Resources Society, 22(1),2002.

Jothivenkatachalam, K., Nithya, A., \& Chandra Mohan, S. Correlation analysis of drinking water quality in and around Perur block of Coimbatore District, Tamil Nadu, India. Rasayan Journal Chemistry, 3(4), 649-654,2010.

Khatoon, N., Khan, A. H., Rehman, M., \& Phatak, V. Correlation study for the assessment of water quality and its parameters of Ganga River, Kanpur, Uttar Pradesh, India. J. Appl. Chem, 5, 80$90,2013$.

Kumar, N., \& Sinha, D. K. An Approach to River Water Quality Management through Correlation Study among Various Water Quality Parameters. Int J Environ Sci, 1(2), 253-259,2010.

Kumar, N., \& Sinha, D. K. Drinking water quality management through correlation studies among various physico-chemical parameters: A case study. International journal of environmental sciences, 1(2), 253,2010.

Mehta, K. V. Physicochemical characteristics and statistical study of groundwater of some places of Vadgamtaluka in Banaskantha district of Gujarat state (India). Journal of Chemical and Pharmaceutical Research,2(4), 663-670,2010.

Mohammad, M. J., Krishna, P. V., Lamma, O. A., \& Khan, S. Analysis of Water Quality using Limnological Studies of Wyra Reservoir, Khammam District, Telangana, India. Int. J. Curr. Microbiol. App. Sci, 4(2), 880-895,2015.

Moharana, J. K., Nanda, P. M., \& Garnaik, B. K. EUTROFICATION DUE TO INDUSTRIALIZATION IN ANGUL-TALCHER INDUSTRIAL COMPLEX OF ODISHA, International Journal of Science, Environment and Technology, Vol. 2, No 1, 2013, 20 - 27,2013.

Nair, G. A., Mohamed, A. I., \& Premkumar, K. Physico chemical parameters and correlation coefficients of ground waters of north-east Libya.Pollution Research, 24(1), 1,2005. 
Nikanorov, A. M., \& Brazhnikova, L. V .Water chemical composition of rivers, lakes and wetlands. Types and Properties of Water, 2, 42-80,2009.

Patel, J. Y., \& Vaghanib, M. V. Correlation Study for Assessment of Water Quality and Its Parameters of Par River Valsad, Gujarat, India, International Journal of Innovative and Emerging Research in Engineering Volume 2, Issue 2, 2015.

Rastogi, G. K., \& Sinha, D. K .A novel approach to water quality management through correlation study. Journal of Environmental Research And Development Vol, 5(4), 2011.

Shah, K. A., \& Joshi, G. S. Evaluation of water quality index for River Sabarmati, Gujarat, India. Applied Water Science, 1-10,2015.

Sharma, P., Meher, P. K., Kumar, A., Gautam, Y. P., \& Mishra, K. P. Changes in water quality index of Ganges river at different locations in Allahabad. Sustainability of Water Quality and Ecology, 3, 6776,2014 .

Singanan, M., Rao, K. S., \& Rambabu, C. A Correlation study on physico-chemical characteristics of ground water in Rameswaramlsland.Ind. J. Environ. Prot, 15, 212-217, 1995.

THAKOR, F. J., BHOI, D., DABHI, H., PANDYA, S., \& CHAUHAN, N. B. Water Quality Index (WQI) of Pariyej Lake Dist. Kheda-Gujarat, Current World Environment Vol. 6(2), 225-231 (2011).

Tripathi, B., Pandey, R., Raghuvanshi, D., Singh, H., Pandey, V., \& Shukla, D. N. Studies on the Physico-chemical Parameters and Correlation Coefficient of the River Ganga at Holy Place Shringverpur, Allahabad. IOSR J. Env. Sc., Toxic. and Food Tech, 8(10), 29-36,2014.

Umavathi, S., Logankumar, K., Subhashini, S., \& Logaswamy, S. Studies on the nutrient content of sulurpondCoimbatore. ECOLOGY ENVIRONMENT AND CONSERVATION, 13(3), 501, 2007.

Venkatesharaju, K., Ravikumar, P., Somashekar, R. K., \&Prakash, K. L. Physico-chemical and bacteriological investigation on the river Cauvery of Kollegal stretch in Karnataka. Kathmandu University Journal of Science, Engineering and Technology, 6(1), 50-59, 2010.

Yadav, A. K., Khan, P., \& Sharma, S. K. Water Quality Index Assessment of Groundwater in Todaraisingh Tehsil of Rajasthan State, India-A Greener Approach. Journal of Chemistry, 7(S1), S428-S432,2010. 